\title{
Antioxidant properties and color characteristics of sponge cakes containing functional components
}

\author{
Zhivka Goranova ${ }^{1}$, Marianna Baeva ${ }^{2}$, Radka Vrancheva ${ }^{2}$, \\ Todorka Petrova ${ }^{1}$, Stefan Stefanov ${ }^{2}$ \\ 1 - Institute of Food Preservation and Quality, Plovdiv, Bulgaria \\ 2 - University of Food Technologies, Plovdiv, Bulgaria
}

\section{Keywords:}

Cake

AntioxidantColor

Jerusalem artichoke

Cocoa husk

Einkorn

\section{Article history:}

Received 03.09.2018

Received in revised

form 11.02.2019

Accepted 31.05.2019

\section{Corresponding \\ author:}

Zhivka Goranova

E-mail:

jivka_goranova@ abv.bg

DOI: $10.24263 / 2304-$

974X-2019-8-2-6

\section{Abstract}

Introduction. This study had investigated the effects of the addition of functional components (Jerusalem artichoke, cocoa husks and einkorn) on the color, antioxidants, and functional properties of sponge cakes.

Materials and methods. The antioxidant activities of sponge cakes were evaluated by methods: ABTS, CUPRAC, FRAP and DPPH assay. Sample analysis also included measurement of color properties in CIEL*a*b* color system using colorimeter.

Results and discussion. The smallest antioxidant activity was observed in $100 \%$ wheat flour cake (control) evaluated by four methods, as DPPH no detected. The antioxidant activity on cocoa husks powder and cake prepare with cocoa husks has been reported on the four methods for different mechanisms of antioxidant action. The antioxidant activity of functional components - cocoa husks powder and einkorn wholemeal flour, is the highest determined by CUPRAC-assay $(203,75 \pm$ $0,55 \mathrm{mM}$ TE/g DM; 117,94 $\pm 0,24 \mathrm{mM}$ TE/g DM) and ABTSassay $(107,55 \pm 0,68 \mathrm{mM}$ TE/g DM; 520,85 $\pm 5,71 \mathrm{mM} \mathrm{TE} / \mathrm{g}$ DM), respectively. The sponge cake with $50 \%$ einkorn wholemeal flour could be developed as a functional food with more effective antioxidant properties. The lightness

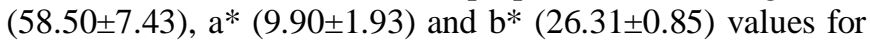
crust control were not significantly different from those of the cake with einkorn wholemeal flour $\left(\mathrm{L}^{*}=60.48 \pm 6.27\right.$; $\mathrm{a}^{*}=$ $\left.9.42 \pm 1.69 ; b^{*}=25.68 \pm 1.44\right)$, so carotenoids and lutein was considered to give a good approximation to the color that einkorn wholemeal flour communicates to cakes. The crumb color on the control sample was similar to that of the cake with einkorn wholemeal flour. According to these results, cakes with Jerusalem artichoke $(\Delta \mathrm{E}=6.62)$ and cocoa husks where $(\Delta \mathrm{E}=23.53)$ the total color difference was appreciable by the human eye.

Conclusions. The sponge cake with einkorn wholemeal flour is with more effective antioxidant properties. The color on the control was similar to that of the cake with einkorn wholemeal flour. 


\section{Introduction}

The quality of cake depends on the quantity and quality of ingredients especially the flour used in preparation. It was found that mixing two or more of different materials will help to solve the deficiency problem of cereal as low nutritional value. Special attention has given to the use of natural antioxidant because of the world wide trend to avoid or minimize synthetic food additives [1]. Flour contributes a major portion of cake and replacement of refined flour with nutrient-rich flour enhances nutritional profile but makes product development tricky. The production of cake from wheat, soybeans, cassava flour, maize flour and lupin flour has been reported [2, 3] .

Research studies and consumer demands show that natural products can be used to improve the textural and functional properties of cakes. Studies [4] reported that the use of barley flour in cakes affects nutritional and functional properties. Apple pomace incorporated into wheat flour led to higher acceptable quality of the cakes with $14.2 \%$ fibre content when $25 \%$ flour was replaced with apple pomace [5]. Green tea powder substituting some flour in sponge cakes pro duced a green tea cake with more effective antioxidant properties, as well as higher content of dietary fibre [6]. In other studies [7] banana powder was replaced with flour. According to the results, sponge and layer cakes with the inclusion of ripe banana generally led to a decline in the specific volume and hardness compared to the control. Changes found in the colour of the crumb and crust are similar for sponge and layer cakes, with darker crumbs and crusts as ripe banana flour is incorporated. These changes should be explained by the darker colour of banana flour resulted from the browning, suffered during the drying process of these flours. By the replacement of wheat flour with gamma aminobutyric acid, the bioactive characteristics of cakes were increased and this was found to be beneficial to human health [8]. Some studies have disclosed the potential sources of natural antioxidants on the bakery products. For example, the rye bread showed better antioxidant properties and higher antioxidant contents when compared to wheat roll $[6,9]$.

The addition of different flours to bakery products creates an opportunity to combine beneficial technological properties with beneficial biological health promoting properties.

\section{Literature review}

Sponge cake is a type of sweet bakery product characterized by its aerated and soft crumb and by its thin coloured crust. This product is produced all over the world and is decorated with different fillings, colours and flavours to create different kinds of cakes. In general, it is associated with celebrations and meetings, and it must fit to high-quality standards required by the consumers [10].

As health promoting substances, phytochemical and nonnutritive substances can be considered functional in foods $[11,12]$.

The cacao husks are considered as a valued source of dietary fibers, mineral elements on the basis of potassium, magnesium, calcium, proteins with balanced amino acidic composition, and polyphenolic compounds which manifest a strong antioxidant activity [1315]. Consumption of dietary fibers offers health benefits including protection against cardiovascular diseases, cancer, reduction blood serum cholesterol and regulation of blood glucose levels [16]. Cocoa pod husk are used traditionally as medicine to treat the pains of pregnancy, fever and coughs [17]. It is proved [13] that in cacao beans husks the quantity of dietary fibre varies from $38 \%$ to $44 \%$, as the mean insoluble fibre concentration is $64.5 \%$ of total fibre quantity. A study [18] was made of the texture, composition, appearance, colour 


\section{— Food Technology —}

and descriptive sensory analysis of low-fat chocolate muffins in which part of the oil ingredient $(25 \%, 50 \%$ and $75 \%)$ had been replaced by soluble cocoa fibre and full-fat (no fat replacement) control sample to which cocoa powder had been added for comparison purposes. The results indicate that soluble cocoa fibre is an encouraging option for replacing oil in a chocolate muffin formulation. The main advantages were that adding soluble cocoa fibre gave muffins higher moisture and a more tender and crumbly texture, as they were more fragile than the control, and reduced the signs of hardening during storage.

Jerusalem artichoke powder made from Jerusalem artichoke (Helianthus tuberosus L.) roots is a valuable product, rich in inulin, as well as vitamins and minerals. According patent by Zhelenkov [1999] has developed and published new technologies for the preparation of confectionary, baker's and pastry products with which the biologically active substances in topinambur flour defining its curative, preventive and dietetic properties are kept. He has recommended the inserting of topinambur flour in confectionaries and pastry food products to be in optimum quantity from 1 to $10 \%$ of the total mass of the components according the recipe. Products of fructans-containing plants such as Jerusalem artichoke become increasingly interesting for application in food as they do not contain bitter taste compounds and therefore constitute a palatable functional ingredient, which may be applied as substitute of cereal flour in bakery products. Koryachkina et al. [19] have regarded the possibilities for the use of topinambur flour in the production of pastry food goods intended to ill people with sugar diabetes type 2. In the same aspect Sinyakovskaya et al. [20] suggest compositions and technologies of sugar-free and sweetened biscuits containing flour of topinambur tubers. The have found that the inserting of topinambur flour in sweetened and sucrose-free biscuits (with sorbitol or fructose) in amount up to 7 and up to $5 \%$ of white wheat flour mass, respectively, has not worsened the structural and mechanical properties of the sponge cakes and biscuits. The topinambur flours brings to both kinds of biscuits a sweet taste, specific odor, brown color with gray nuance, and on the other hand decreases their energetic value and increases their biological activity.

Fibers, and more particularly the soluble ones, like inulin and fructooligosaccharides (FOS), are known to provide health benefits like stimulation of beneficial colonic bacteria (prebiotic capacity), reduction in bowel transit time, increase mineral absorption, improve immune response, and prevent diseases like intestinal infections, colorectal cancers, obesity, cardiovascular diseases and type II diabetes[21, 22].

Einkorn (Triticum monococcum L.) is a diploid hulled wheat appreciated for its excellent nutritional properties, including high protein, carotenoids, $\beta$-glucans and antioxidants contents [23-25], and as such it is a promising candidate for the development of functional bakery products. Einkorn-enriched cookies had higher ash, polyphenols, carotenoids, antioxidants and beta-glucans content than pure wheat flour cookies, and might possibly be classified as functional foods [25]. Einkorn wheat flour is suitable for the development of lutein-rich functional foods because lutein amounts to $8.41 \mu \mathrm{g} . \mathrm{g}-1 \mathrm{~d} . \mathrm{m}$. on average [24]. Such food products are extremely healthful in old age because ageing patients suffer from macular degeneration which may result in blindness [23].

Current studies into free radicals have confirmed that foods rich in antioxidants play an essential role in the prevention of cardiovascular diseases and cancers and neurodegenerative diseases, as well as inflammation and problems caused by cell and cutaneous aging [26, 27].

Since some of synthetic antioxidants had toxigenic, mutagenic, and carcinogenic effects and some natural antioxidants were effective in enhancing the shelf life of bakery products but less effective than synthetic antioxidants, there is a great demand for the use of new natural antioxidants in food, especially in bakery products $[6,28,29]$. 
Color is one of the major attributes which affects the consumer perception of quality, holds a preeminent position in food acceptance [30]. At the point of purchase the consumer uses appearance factors to provide an indication of freshness and flavor quality. Consumers have a preferred color for a specific item [31].

The application of colorimetry offers an objective way of color assessment because it is based on the whole visible spectrum and makes it possible to obtain the real chromatic profile of food products. The objective measurement of color is of great importance for food producers due to the relationship existing between color and the acceptability [32].

Change of biscuits color during baking was a dynamic process in which transitory colors occurred as result of baking. The biscuits from $100 \%$ barley flour, a very visible change of color has been noticed even after $5 \mathrm{~min}$. of baking $(\Delta \mathrm{E}>6)$. From stored biscuits, the biggest change of color has been noticed with biscuits from $100 \%$ wheat flour after $6(\Delta \mathrm{E}=16.49)$ and 12 months $(\Delta \mathrm{E}=14.29)$ of storage. Browning development in biscuits begins when sufficient amount of drying has occurred. Moreover it was associated with the recipe (reducing sugars, leavening agents, salt, amino acids, etc.) and baking conditions (temperature and time). Browning was the final step of both the Maillard reaction and caramelization, one of the end-points of the baking process and the final result of sugar degradation during baking [33].

The above-presented brief review on available data clearly identifies the lack of sufficient scientific evidence about the effects of these functional components on cakes antioxidant properties and color characteristics.

The aim of this work was to evaluate color and antioxidant properties of sponge cakes enriched with functional components (Jerusalem artichoke powder, cocoa husk powder and einkorn wholemeal flour) and its utilization partially, substituted of wheat flour at levels of $20 \%, 35 \%, 50 \%$ as a natural source of antioxidants in cake making.

\section{Materials and methods}

\section{Materials and sponge cakes preparation}

Raw materials such as wheat flour of type 500 - ash content $0.5 \%$ (GoodMills, Bulgaria EAD), granulated sugar (Zaharni zavodi AD), eggs (local market) used in the current study. A control cake was prepared, following a traditional technology and formulation [34]. The batter formulation of the control cake was as follows (based on flour weight): egg yolk $43.23 \%$, egg white $96.77 \%$, refined granulated sugar $83.87 \%$, and wheat flour $100 \%$. In particular, a double mixing procedure was applied by partitioning whipping of whites and egg yolks. Jerusalem artichoke powder (JAP), cocoa husk powder (CHP) and einkorn wholemeal flour (EWF) were added into sponge cake flour at different levels 20, 35 and 50\%, by replacing wheat flour, respectively. Each sponge cakes batter of $95 \mathrm{~g}$ was poured out in metallic forms and baked in an electric oven at $180^{\circ} \mathrm{C}$ for $30 \mathrm{~min}$.

\section{Evaluation of antioxidant activities of flours and sponge cakes}

DPPH radical scavenging activity. The ability of the extracts to donate an electron and scavenge DPPH radical was determined by the slightly modified method of Brand-Williams et al. [35]. Freshly prepared $4 \times 10^{-4}$ mol methanol solution of DPPH was mixed with the samples in a ratio of 2:0.5 (v/v). The light absorption was measured at $517 \mathrm{~nm}$. The DPPH radical scavenging activity was presented as a function of the concentration of Trolox ${ }^{\circledR}$ - 
Trolox ${ }^{\circledR}$ equivalent antioxidant capacity (TEAC) and it was defined as the concentration of Trolox ${ }^{\circledR}$ having equivalent AOA expressed as $\mu \mathrm{mol} \mathrm{TE} / \mathrm{g} \mathrm{dw}$.

ABTS radical scavenging assay. The radicals scavenging activity of the investigated extracts against radical cation (ABTS $\bullet$ ) was estimated according to the previously reported procedure with slight modifications [36]. The results were expressed as TEAC value ( $\mu \mathrm{mol}$ $\mathrm{TE} / \mathrm{g} \mathrm{dw}$ ).

Ferric-reducing antioxidant power assay (FRAP). The FRAP assay was carried out according to the procedure of Benzie and Strain (1996) [37]. FRAP assay measures the change in absorbance at $593 \mathrm{~nm}$ owing to the formation of a blue colored Fe (II)tripyridyltriazine compound from colorless oxidized Fe (III) form by the action of electron donating antioxidants. The results were expressed as $\mu \mathrm{mol} \mathrm{TE} / \mathrm{g} \mathrm{dw}$.

Cupric ion reducing antioxidant capacity assay (CUPRAC). To a test tube, the solutions were added as follow: $1 \mathrm{~mL}$ of $\mathrm{CuCl} 2$ solution $\left(1.0 \times 10^{-2} \mathrm{M}\right), 1 \mathrm{~mL}$ of neocuproine methanol solution $\left(7.5 \times 10^{-3} \mathrm{~mol}\right)$, and $1 \mathrm{~mL} \mathrm{NH4Ac} \mathrm{buffer} \mathrm{solution}(\mathrm{pH} 7.0)$, and mixed; $0.1 \mathrm{~mL}$ of sample followed by $1 \mathrm{~mL}$ of water was added (total volume $=4.1 \mathrm{~mL}$ ), and mixed well. Absorbance against a reagent blank was measured at $450 \mathrm{~nm}$ after $30 \mathrm{~min}$ [38]. Trolox was used as standard and total antioxidant capacity of herbal extracts was measured as $\mu \mathrm{mol}$ $\mathrm{TE} / \mathrm{g} \mathrm{dw}$.

\section{Measurement of color of sponge cakes}

The instrumental measurement of the cakes color was carried out with a colorimeter Color-guide 45/0 Colorimeter, BYK-Gardner Inc, USA, and the results were expressed in accordance with the CIELAB system. Color was measured at four predetermined places of the sponge cakes crust and crumb. The parameters determined were $\mathrm{L}^{*}\left(\mathrm{~L}^{*}=0\right.$ [black] and $\mathrm{L}^{*}=100$ [white] $), \mathrm{a}^{*}\left(-\mathrm{a}^{*}=\right.$ greenness and $+\mathrm{a}^{*}=$ redness $), \mathrm{b}^{*}\left(-\mathrm{b}^{*}=\right.$ blueness and $+\mathrm{b}^{*}=$ yellowness). The dominant wavelength (DW) of a color $=a^{* /} b^{*}$ (color tone).

$$
\mathrm{DW}=\mathrm{a} * / \mathrm{b}^{*}
$$

Colorimeters give measurements that can be correlated with human eye-brain perception, and give tristimulus $\left(\mathrm{L}^{*}, \mathrm{a}^{*}\right.$ and $\mathrm{b}^{*}$ ) values directly. Determined is correlation between color parameters and visual sensory evaluation of color (TC) $[39,40]$.

Chroma, $\mathrm{C}^{*}$, is the aspect of color in by which a sample appears to difference from a gray of the same lightness or brightness, as defined by the following equations:

$$
\mathrm{C} *=\sqrt{\mathrm{a}}{ }^{2}+\mathrm{b}^{* 2}
$$

The total color difference $\left(\Delta \mathrm{E}^{*}\right)$ between the control cake and the sponge cakes with functional ingredients was calculated as follows:

$$
\Delta \mathrm{E}^{*}=\sqrt{ }(\Delta \mathrm{L} *)^{2}+\left(\Delta \mathrm{a}^{*}\right)^{2}+\left(\Delta \mathrm{b}^{*}\right)^{2}
$$

as: $\Delta \mathrm{L}^{*}=\mathrm{L}_{1}-\mathrm{L}_{0} ; \Delta \mathrm{a}^{*}=\mathrm{a}_{1}-\mathrm{a}_{0} ; \Delta \mathrm{b}^{*}=\mathrm{b}_{1}-\mathrm{b}_{0}$.

The values used to determine if the total color difference was visually obvious were the following.

$\Delta \mathrm{E}^{*}<1$ color differences are not obvious for the human eye;

$1<\Delta \mathrm{E}^{*}<3$ color differences are not appreciative by the human eye;

$\Delta \mathrm{E}^{*}>3$ color differences are obvious for the human eye $[39,41]$. 


\section{Results and discussion}

\section{Evaluation of antioxidant activities of flours and sponge cakes}

The results from antioxidant activities of sponge cakes were presented (Figure 1) evaluated by four methods, based on different mechanism (DPPH, ABTS, FRAP and CuPRAC). The antioxidant activity in the einkorn wholemeal flour saved when the batters were baked.

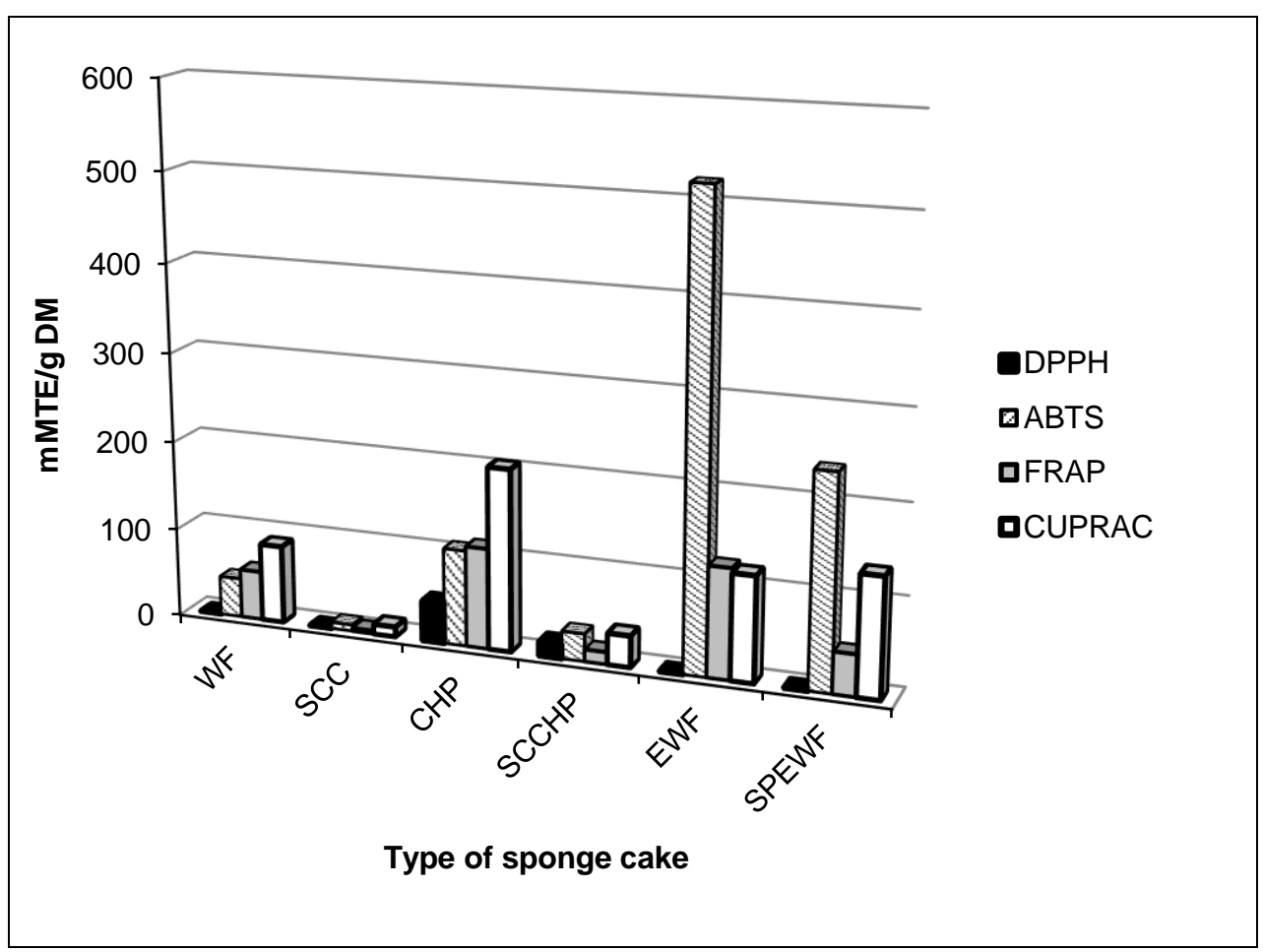

Figure 1. Antioxidant activity (mMTE/g DM) in flours and sponge cakes:

$\mathrm{WF}$ - wheat flour;

SCC - sponge cake control;

CHP - cocoa husks powder;

SCCHP - sponge cake with $35 \%$ cocoa husks powder;

EWF - einkorn wholemeal flour; SCEWF - sponge cake with 50\% einkorn wholemeal flour.

** mM Trolox Equivalents/g dry matter

The smallest antioxidant activity was observed in $100 \%$ wheat flour cake (control) evaluated by four methods, as DPPH no detected.

The total antioxidant capacity determined by the free radical scavenging activity (DPPHassay) of cocoa husks powder and sponge cake with 35\% cocoa husks powder is 45.03 and $15.89 \mathrm{mM}$ TE/g DM. The antioxidant properties for cakes with functional components determined by ferric reducing antioxidant power (FRAP-assay) for cake with $35 \%$ cocoa 
husks powder $-30.88 \mathrm{mM} \mathrm{TE} / \mathrm{g} \mathrm{DM}$ and the cake with $50 \%$ einkorn wholemeal flour is $237.53 \pm 7.08 \mathrm{mM}$ TE/g DM. The antioxidant activity of functional components - cocoa husks powder and einkorn wholemeal flour, is the highest determined by CUPRAC-assay (203.75 mM TE/g DM) and ABTS-assay (520.85 mM TE/g DM), respectively.

The cakes with $35 \%$ cocoa husks powder and control have highest the antioxidant activity on CUPRAC, as sponge cake with $50 \%$ einkorn wholemeal flour the highest scores are evaluated in relation to the free radical ABTS. Of the two methods of electron transfer (FRAP и CUPRAC), CUPRAC shows a higher antioxidant capacity compared to the samples tested. The antioxidant activity on cocoa husks powder and cake prepare with cocoa husks has been reported on the four methods for different mechanisms of antioxidant action.

A significantly higher content in conjugated phenols and total carotenoids was reported in water cookies with T. monococcum [42, 43], and was attributed to the superior concentration in einkorn kernels and flour of these compounds.

The sponge cake with $50 \%$ einkorn wholemeal flour could be developed as a functional food with more effective antioxidant properties.

\section{Color of sponge cakes}

Measurements of color properties for the tested compositions of sponge cakes with different functional components were conducted on crust and crumb of fresh cakes.

Crust color of cakes. The lightest samples (highest $\mathrm{L}^{*}$ values) were those in which $50 \%$ of the flour had been replaced by einkorn wholemeal flour; the lightness values fell significantly as add $20 \%$ Jerusalem artichoke powder (49.60 \pm 6.73$)$. The sponge cake with $35 \%$ cocoa husks powder had lowest values of $\mathrm{a}^{*}$ and $\mathrm{b}^{*}$ indicating a significantly brighter and more saturated brown-orange colour (Table 1).

Table 1

Crust color values of sponge cakes

\begin{tabular}{|c|c|c|c|c|}
\hline \multirow{2}{*}{$\begin{array}{c}\text { Color } \\
\text { characteristics }\end{array}$} & \multicolumn{4}{|c|}{ Type of sponge cake } \\
\cline { 2 - 5 } $\mathbf{L}^{*}$ & Control & With JAP & With CHP & With EWF \\
\hline $\mathbf{a}^{*}$ & $58.50 \pm 7.43$ & $49.60 \pm 6.73$ & $54.16 \pm 2.48$ & $60.48 \pm 6.27$ \\
\hline $\mathbf{b}^{*}$ & $9.90 \pm 1.93$ & $10.45 \pm 1.10$ & $7.63 \pm 0.87$ & $9.42 \pm 1.69$ \\
\hline $\mathbf{D W}$ & $26.31 \pm 0.85$ & $23.99 \pm 1.47$ & $20.13 \pm 1.37$ & $25.68 \pm 1.44$ \\
\hline $\mathbf{C}^{*}$ & 0.38 & 0.44 & 0.38 & 0.37 \\
\hline$\Delta \mathbf{E}$ & 28.11 & 26.17 & 21.53 & 27.35 \\
\hline TC & - & 9.21 & 7.88 & 2.14 \\
\hline
\end{tabular}

${ }^{1}$ The values are average $\pm \mathrm{SD}(\mathrm{p} \leq 0.05)$.

The samples with 50\% einkorn wholemeal flour and control have the highest values of b* (yellow component) indicating a significantly brighter and more saturated yellow color. The lightness, $a^{*}$ and $b^{*}$ values for control were not significantly different from those of the cake with einkorn wholemeal flour, so carotenoids and lutein was considered to give a good approximation to the color that einkorn wholemeal flour communicates to cakes. The same products had the highest value of chroma of crust. The lowest values for chroma were detected at the crust for the cake containing cocoa husks as fiber source. The dominant 
wavelength (DW) of a color at crust have the highest values on cake containing Jerusalem artichoke powder. According to these results, cakes with Jerusalem artichoke and cocoa husks where the $\Delta \mathrm{E}^{*}$ was appreciable by the human eye $\left(\Delta \mathrm{E}^{*}>3\right)$. According MartínezCervera et al. [18] adding soluble cocoa fibre gave a fair change of color in muffins.. However, there are points that require improvement, such as the loss of height, perception of bitter taste and a certain surface stickiness.

The correlation between color parameters on crust and visual sensory evaluation of color (TC) on the control sample was similar to that of the cake with einkorn wholemeal flour.

Crumb color of cakes. The variations in the crumb color of the cakes with functional components as flour replacer were similar to the variations in crust color (Table 2). The cake with einkorn wholemeal flour was the lightest and the $b^{*}$ values showed that this sample had a brighter color. The crumb color on the control sample was similar to that of the cake with einkorn wholemeal flour. The color tone of crumb have the highest values on cake containing cocoa husks. The lowest values for chroma were detected at the crumb for the cake containing Jerusalem artichoke powder as fructooligosaccharide source. This would be in agreement with the $\Delta \mathrm{E}^{*}$ values, where only the einkorn wholemeal replacement formulation showed a color difference that was not appreciable by the human eye $\left(\Delta \mathrm{E}^{*}<3\right)$. Gedrovica \& Karklina [44] studied characteristics of cakes enriched with Jerusalem artichoke powder /flour of topinambur tubers/ at a concentration of 10, 20,30,40,50\%. The cakes enriched with Jerusalem artichoke powder (at a concentration of 30 and 40\%) stayed soft longer during the storage time (two days) than control samples without this powder. The highest content of moisture was observed in cakes enriched with Jerusalem artichoke powder at a concentration of 20 and $30 \%$. The concentration of Jerusalem artichoke powder and moisture with a probability of $95 \%$ substantially influenced the color components $\mathrm{L}^{*} \mathrm{a} * \mathrm{~b} *$. The highest changes in color were reflected by the values $\mathrm{L}^{*}$ (darkness) $\mathrm{a}^{*}$ (redness). The best quality of cakes was determined in samples with a 30\% addition of Jerusalem artichoke powder. Determined is correlation between color parameters and visual sensory evaluation of color (TC), as the highest values for crumb cake have product with cocoa husks.

Crumb color values of sponge cakes

Table 2

\begin{tabular}{|c|c|c|c|c|}
\hline \multirow{2}{*}{$\begin{array}{c}\text { Color } \\
\text { characteristics }\end{array}$} & \multicolumn{4}{|c|}{ Type of sponge cake } \\
\cline { 2 - 5 } & Control & With JAP & With CHP & With EWF \\
\hline L* $^{*}$ & $59.41 \pm 5.34$ & $52.84 \pm 1.07$ & $36.27 \pm 4.11$ & $60.88 \pm 2.69$ \\
\hline $\mathbf{a}^{*}$ & $0.96 \pm 0.86$ & $1.35 \pm 0.32$ & $5.16 \pm 0.56$ & $1.47 \pm 0.47$ \\
\hline $\mathbf{b}^{*}$ & $13.11 \pm 1.64$ & $12.36 \pm 1.39$ & $13.79 \pm 2.74$ & $15.17 \pm 1.24$ \\
\hline $\mathbf{D W}$ & 0.07 & 0.11 & 0.37 & 0.10 \\
\hline $\mathbf{C}^{*}$ & 13.15 & 12.43 & 14.72 & 15.24 \\
\hline$\Delta \mathbf{E}$ & - & 6.62 & 23.53 & 2.58 \\
\hline TC & 2.46 & 4.11 & 19.32 & 3.17 \\
\hline
\end{tabular}

${ }^{1}$ The values are average $\pm \mathrm{SD}(\mathrm{p} \leq 0.05)$. 


\section{- Food Technology}

\section{Conclusion}

Sponge cakes with functional components had higher levels of antioxidants and antioxidant activity when compared with their respective controls. The antioxidant activity in the einkorn wholemeal flour saved when the batters were baked. Results of instrumental measurements of color of crust and crumbe of sponge cakes, obtained with the colorimetry (in CIE and CIE L*a*b* systems) are in good agreement with sensory evaluations of color and brightness of cake samples. The lightness, $\mathrm{a}^{*}$ and $\mathrm{b}^{*}$ values for crust control were not significantly different from those of the cake with einkorn wholemeal flour, so carotenoids and lutein was considered to give a good approximation to the color that einkorn wholemeal flour communicates to cakes. The crumb color on the control sample was similar to that of the cake with einkorn wholemeal flour. According to these results, cakes with Jerusalem artichoke and cocoa husks where the $\Delta \mathrm{E}^{*}$ was appreciable by the human eye. As a result of the good functionality of used functional components in cake formulation, were very good ingredient in composite flours.

\section{References}

1. Al-Sayed H. M. A. \& Ahmed A. R. (2013), Utilization of watermelon rinds and sharlyn melon peels as a natural source of dietary fiber and antioxidants in cake, Annals of Agricultural Science, 58 (1), pp. 83-95.

2. Onuegbu N.C., Ihediohanma N.C., Odunze O.F. and Ojukwu M. (2013), Efficiency of wheat: Maize composite flour as affected by baking method in bread and cake production. Sky J. Food Sci. 2, pp. 5-13.

3. Ahmed A.R. (2014), Influence of chemical properties of wheatlupine flour blends on cake quality, Am. J. Food Sci. Technol. 2, pp. 67-75.

4. Yaqoob S., Baba W. N., Masoodi F. A., Shafi M., Bazaz R. (2018), Effect of sprouting on cake quality from wheat-barley flour blends, Journal of Food Measurement and Characterization, 12(2), pp. 1253-1265.

5. Sudha M.L., Baskaran V., Leelavathi K., (2007), Apple pomace as a source of dietary fiber and polyphenols and its effect on the rheological characteristics and cake making, Food Chemistry 104 (2), pp. 686-692.

6. Lu T.M., Lee C.C., Mau J.L., Lin S.D., (2010), Quality and antioxidant property of green tea sponge cake, Food Chemistry, 119, pp. 1090-1095.

7. Segundo C., Román L., Lobo M., Martinez M., Gómez M. (2017), Ripe banana flour as a source of antioxidants in layer and sponge cakes, Plant Foods Hum Nutr., 72(4), pp. 365-371.

8. Uçar B. \& Hayta M. (2018), Bioactive and physicochemical properties of wild fruit powder added sponge cake, Food and Health, 4(4), pp. 254-263.

9. Michalska A., Ceglinska A., Amarowicz R., Piskula M. K., Szawara-Nowak D. \& Zielinski H. (2007), Antioxidant contents and antioxidative properties of traditional rye breads, Journal of Agricultural and Food Chemistry, 55, pp. 734-740.

10. Ureta M., Olivera D. \& Salvadori V. (2017), Influence of baking conditions on the quality attributes of sponge cake, Food Science and Technology International 23(2), pp. $156-165$.

11. Conforti F. D. \& Davis S. F. (2006), The effect of soya flour and flaxseed as a partial replacement for bread in yeast bread, International Journal of Food Technology, 41, pp. 95-101. 
12. Simakhina G., Naumenko N., Khalapsina S., (2012), Biological value of aronia berries, Ukrainian Food Journal, 1 (1), pp. 8-12.

13. Bonvehi J. S. \& Coll F. V. (1999), Protein quality assessment in cocoa husk, Food Research International, 32, pp. 201-208.

14. Chung B. Y., Iiyama K. \& Han K. (2003), Compositional characterization of cacao (Theobroma cacao L.) hull, Agricultural Chemistry and Biotechnology, 46, pp. 12-16.

15. Lecumberri E., Mateos R., Izquierdo M., Ruperez P., Goya L. \& Bravo L. (2007), Dietary fibre composition, antioxidant capacity and physico-chemical properties of a fibre-rich product from cocoa (Theobroma cacao L.), Food Chemistry, 104 (3), pp. 948954.

16. Qiang X., Yong Lie C. \& Qian Bing W. (2009), Health benefit application of functional oligosaccharides. Carbohydrate Polymers, 77 (3), pp. 435-441.

17. Oyeyemi S. D., Tedela P. O. \& Oyedeji O. E. (2017), Assessment of the nutritional potentials of Theobroma cacao L. and Coffee liberica W. Bull., Ukrainian Food Journal, 6 (2), pp. 258-268.

18. Martínez-Cervera S., Salvador A., Muguerza B., Moulay L., Fiszman S. M. (2010), Cocoa fibre and its application as a fat replacer in chocolate muffins, $L W T-$ Food Science and Technology, 44, pp. 729-736.

19. Koriachkina S. I., Kalinina V. S. \& Ladnova O. L. (2003), Razrabotka muchnykh konditerskikh izdelii diabeticheskogo naznacheniia, Uspekhi sovremennogo estvestvoznaniia, 12, pp. 79-81.

20. Available at: www.topinambur.net

21. Praznik W., Cieslik E. \& Filipak-Florkiewicz, A. (2002), Soluble dietary fibres in Jerusalem artichoke powders: Composition and application in bread, Nahrung, 46 (3), pp. 151-157.

22. Rubel I. A., Perez E. E., Genovese D. B. \& Manrique G. D. (2015), Fibre enrichment of wheat bread with Jerusalem artichoke inulin: Effect on dough rheology and bread quality, Food Structure, 3, pp. 21-29.

23. Abdel-Aal E.-S. M., Young J. C., Wood P. J., Rabalski I., Hucl P., Falk D. \& FregeauReid J. (2002), Einkorn: A potential candidate for developing high lutein wheat, Cereal Chemistry, 79, pp. 455-457.

24. Hidalgo A., Brandolini A., Pompei C. \& Piscozzi R. (2006), Carotenoids and tocols of einkorn wheat (Triticum monococcum ssp. monococcum L.), Journal of Cereal Science, 44 (2), pp. 182-193.

25. Nakov G., Brandolini A., Ivanova N., Dimov I. \& Stamatovska V. (2018), The effect of einkorn (Triticum monococcum L.) whole meal flour addition on physico-chemical characteristics, biological active compounds and in vitro starch digestion of cookies, Journal of Cereal Science, 83, pp. 116-122.

26. Park S. H., Lim H. S. \& Hwang S. Y. (2012), Evaluation of antioxidant, rheological, physical and sensorial properties of wheat flour dough and cake containing turmeric powder, Food Science and Technology International, 18, pp. 435-443.

27. Blasa M., Gennari L., Argelino D. \& Ninfali P. (2010), Fruit and Vegetable Antioxidants in Health. In: Bioactive Foods in Promoting Health. Fruits and Vegetables, 1st edn, Elsevier Inc, pp. 37-58. https://doi.org/10.1016/B978-0-12-374628-3.00003-7

28. Kiokias S., Varzakas T. \& Oreopoulou V. (2008), In vitro activity of vitamins, flavonoids, and natural phenolic antioxidants against the oxidative deterioration of oilbased systems, Critical Reviews in Food Science and Nutrition, 48, pp. 78-93.

29. Bazhay-Zhezherun S., Antoniuk M. \& Smulska J., (2015), Biologically activated wheat grain as a functional component of glazed bars, Ukrainian Food Journal, 4 (2), pp. 310320. 
30. Sadilek T. (2019), Perception of Food Quality by Consumers: Literature Review, European Research Studies Journal, 22(1), pp. 52-62.

31. Barrett D. M., Beaulieu J. C. \& Shewfelt R. (2010), Color, flavor, texture, and nutritional quality of fresh-cut fruits and vegetables: desirable levels, instrumental and sensory measurement, and the effects of processing, Critical Reviews in Food Science and Nutrition, 50, pp. 369-389.

32. Granato D. \& Masson M. L. (2010), Instrumental color and sensory acceptance of soybased emulsions: a response surface approach, Ciência e Tecnologia de Alimentos, 30 (4), pp. 1090-1096.

33. Nakov G., Komlenić D. K., Stamatovska V., Šušak A. \& Jukić M. (2017), Influence on time of baking and different role of barley flour on the colour of the biscuits, Journal of Hygienic Engineering and Design, 21, pp. 90-95.

34. Angelov L., Bekirov B., Genadieva M. \& Atanasov S. (1974), OH 146 200-72. In Handbook of branch standards, rates of consumption and technological instructions in confectionaryture, I, pp. 176-183.

35. Brand-Williams W., Cuvelier M. \& Berset C. (1995), Use of a free radical method to evaluate antioxidant activity, LWT - Food Science and Technology, 28, pp. 25-30.

36. Re R., Pellegrini N., Proteggente A., Pannala A., Yang M. \& Rice-Evans C. (1999), Antioxidant activity applying an improved ABTS radical cation decolorization assay, Free Radical Biology and Medicine, 26, pp. 1231-1237.

37. Benzie F. \& Srain J. (1996), Ferric reducing ability of plasma (FRAP) as a measure of "antioxidant power", The FRAP assay, Analytical Biochemistry, 239, pp. 70-76.

38. Ak T. \& Gülçin I. (2008), Antioxidant and radical scavenging properties of curcumin, Chemico-Biological Interactions, 174, pp. 27-37.

39. Popov-Raljić J. V. \& Laličić-Petronijević J. G. (2009), Sensory properties and color measurements of dietary chocolates with different compositions during storage for up to 360 days, Sensors 2009, 9 (3), pp. 1996-2016; doi:10.3390/s90301996.

40. Pathare P. B., Opara U. L. \& Al-Said F.A. (2013), Colour Measurement and Analysis in Fresh and Processed Foods: A Review, Food Bioprocess Technology, 6, pp. 36-60.

41. Baixauli R., Salvador A. \& Fiszman S. M. (2008), Textural and colour changes during storage and sensory shelf life of muffins containing resistant starch, European Food Research and Technology, 226, pp. 523-530.

42. Hidalgo A., Brandolini A. \& Pompei C. (2010), Carotenoids evolution during pasta, bread and water biscuit preparation from wheat flours, Food Chemistry, 121, pp. 746751.

43. Hidalgo A., Ferraretto A., De Noni I., Bottani M., Cattaneo S., Galli S. \& Brandolini A. (2018), Bioactive compounds and antioxidant properties of pseudocereals-enriched water biscuits and their in vitro digestates, Food Chemistry, 240, pp. 799-807.

44. Gedrovica I. \& Karklina D. (2009), Characteristics of cakes enriched with Jerusalem artichoke powder, Chemine Technologija, 2009, 3 (52), pp. 50-55. 